\title{
3.В. Салій
}

\section{ВМІСТ АФК ${ }^{+}$PI $^{+}, \mathrm{ANV}^{+}$У ПАЦІЕНТВ IЗ НАСЛІДКАМИ ЧЕРЕПНО- МОЗКОВОЇ ТРАВМИ ЗАЛЕЖНО ВІД МОРФОМЕТРИЧНИХ ХАРАКТЕРИСТИК ГОЛОВНОГО МОЗКУ}

ДВНЗ «Тернопільський державний медичний університет імені І.Я. Горбачевського МОЗ України»

\begin{abstract}
Резюме. У статті наведені результати дослідження вмісту $\mathrm{AФK}^{+}, \mathrm{AnV}^{+}$та $\mathrm{PI}^{+}$у пацієнтів із наслідками ЧМТ залежно від морфометричних характеристик головного мозку. Встановлено достовірно вищі значення показників раннього апоптозу, активацію оксидантного стресу та тенденцію до зростання показників пізнього апоптозу за наявності ознак післятравматичної церебра-
\end{abstract}

Вступ. Черепно-мозкова травма (ЧМТ) може бути пусковим механізмом цілого каскаду молекулярних, нейрохімічних, клітинних і імунних процесів, таких, як порушення гомеостазу кальцію, окиснювальний стрес, вивільнення збудливих нейротрасмітерів, клітинна і мітохондріальна дисфункція, запальна інфільтрація клітин, апоптоз [4]. Ключовою подією в посттравматичній дегенерації нейронів є окиснювальний стрес, коли збільшення вільних радикалів призводить до білкового окиснення, активації перикисного окиснення ліпідів і пошкодження ДНК [5]. Ознаками, що вказують на початок апоптозних змін у клітині, є окиснення ліпідів клітинних мембран, яке відбувається внаслідок надмірної генерації активних форм кисню (АФК ${ }^{+}$.

На думку авторів [7], вторинний каскад відіграє значну роль у пошкодженні нейронів і враховуючи, що процеси при первинному травматичному ураженні мозку є необоротними, саме корекція вторинних процесів має бути основою планування терапевтичних стратегій і випробування нейропротекторів.

У попередній роботі нами встановлено активацію процесів некрозу та апоптозу лейкоцитів периферичної крові у пацієнтів із наслідками ЧМТ та достовірну залежність даного процесу лише від варіанта перебігу травматичної хвороби головного мозку [3]. На відміну від гострого періоду ЧМТ [6], ми не зафіксували статистично достовірного впливу тяжкості та катамнезу перенесеної травми, а також віку хворого на зростання вмісту лейкоцитів мічених анексином та пропідію йодидом, що спонукало до пошуку додаткових факторів.

Одним із проявів дегенеративно-дистрофічних змін є післятравматична церебральна атрофія (ПЦА). Саме вона, на думку авторів $[1,2]$, $\epsilon$ основною причиною вентрикулодилатації, розширення субарахноїдальних просторів і зниження щільності мозкової речовини, які виявляються при проведенні нейровізуалізаційних досліджень.

Мета дослідження. Дослідити наявність зв'язку між морфометричними характеристиками головного мозку і показниками раннього та пізнього апоптозу лейкоцитів периферичної крові. льної атрофії. Зафіксовані особливості динаміки показників $\mathrm{AФK}^{+}$та $\mathrm{AnV}^{+}$у групах із різним катамнезом травми, а також залежність між окремими морфометричними маркерами церебральної атрофії та показниками, що вивчалися.

Ключові слова: активні форми кисню, апоптоз лейкоцитів, наслідки черепно-мозкової травми.

Матеріал і методи. Проведено обстеження 280 пацієнтів із наслідками ЧМТ. Середній вік пацієнтів - $(42,54 \pm 0,59)$ років, катамнез травми $(8,02 \pm 0,49)$ років, чоловіків було $104(84,55 \%)$. Дизайн дослідження передбачав: вік пацієнтів від 18 до 60 років, формування груп за тяжкістю ЧМТ (легка (ЛЧМТ, n=95), середньої тяжкості (СТЧМТ, n=72), тяжка (ТЧМТ, n=113)), катамнезом травми (до 1 року, 1-5 років, 6-10 років та більше 10 років), наявністю морфометричних ознак ПЦА та за видом ПЦА.

Здійснювали якісну і кількісну оцінку отриманих аксіальних томограм головного мозку (апарат Asteion Super 4, Toshiba (Японія)), визначаючи наступні морфометричні характеристики: ширину правого і лівого бічних шлуночків (мм), мінімальні розміри бічних шлуночків на рівні "cella media" (мм), ширину третього шлуночка (мм), розміри субарахноїдальних просторів (мм) на рівні полюса лобових часток, Сільвієвої щілини та потиличної частки. Спираючись на отримані дані, обчислювали морфометричні індекси: фронтальних рогів, тіл бокових шлуночків, бікаудатнотемпоральний, Шлатенбрандта-Нюрнберга, біфронтальний (БФІ), бікаудатний (БКІ), число Хакмана (ЧХ), співвідношення Евана (СЕ) [2].

Для оцінки апоптозу лейкоцитів крові використовували FITC (флюоресцеїн ізотіоціанат) мічений анексин V iз набору реагентів «ANNEXIN V FITC» («Beckman Coulter», СШA). Аналіз проб проводили на проточному цитометрі Epics XL («Beckman Coulter», США) з аргоновим лазером. Дискримінаційний аналіз типу клітинної смерті включав: 2-й квадрант - клітини, позитивні за проридію йодидом $\left(\mathrm{PI}^{+}\right)$i анексином $\mathrm{V}$ $\left(\mathrm{AnV}^{+}\right)$- FITC - пізня стадія апоптозу або некроз; 3-й квадрант - клітини, негативні за РI і анексином V-FITC - життєздатні клітини; 4-й квадрант - клітини, позитивні за анексином V-FITC і негативні за РI - рання стадія апоптозу. Отримані результати представляли у відсотках (співвідношення числа анексин-позитивних клітин до загальної кількості фракцій лейкоцитів).

Рівень продукції АФК аналізували за інтенсивністю світіння барвника дихлорфлюоресцеї- 
нудіацетату («Sigma Aldrich», USA) на проточному цитофлюориметрі Epics XL («Beckman Coulter», США). Значення дослідженого параметра виражали у відсотках [8].

Статистична обробка результатів виконана у відділі системних статистичних досліджень ДВНЗ «Тернопільський державний медичний університет імені І.Я. Горбачевського МОЗ України» за допомогою програмного пакета Statsoft Statistica.

Результати дослідження та їх обговорення. За морфометричними характеристиками головного мозку 280 пацієнтів були розподілені на дві групи - 3 проявами церебральної атрофії (n=142, середній вік $(43,85 \pm 0,85)$ років, термін травми $(7,69 \pm 0,69)$ років) та без знак останньої $(n=138$, середній вік $(41,25 \pm 0,80)$ років, термін травми $(8,36 \pm 0,70)$ років). Відсоток клітин у стадії некрозу в першій групі $1,83 \pm 0,09 \%$, проти $1,67 \pm 0,12 \%$ - у другій, ( $\mathrm{p}=0,27)$, відсоток клітин у стадії апоптозу $29,95 \pm 0,75 \%$ проти $25,83 \pm 0,73 \%,(p=0,000)$. У пацієнтів із морфометричними ознаками ПЦА вміст АФК $^{+}$становив 41,00 $\pm 1,12 \%$, проти $36,64 \pm 0,93 \%, \quad(p=0,004)$. Співвідношення $\mathrm{PI}^{+} /$ $\mathrm{AnV}^{+}$у першій групі 1:16,4, у другій - 1:15,5.

Отже, за наявності ознак ПЦА, зафіксовано достовірно вищі значення показників раннього апоптозу, активацію оксидантного стресу та тенденцію до зростання показників пізнього апоптозу. Дослідження кореляційних зв'язків між окремими морфометричними індексами та даними лабораторного дослідження підтвердило наявність слабкого рівня достовірної залежності між відсотком АФК ${ }^{+}$та шириною бічних шлуночків (правого $\mathrm{r}=0,162, \mathrm{p}=0,007$, лівого - $\mathrm{r}=0,218$, $\mathrm{p}=0,000)$, ЧХ $(\mathrm{r}=0,156, \mathrm{p}=0,008)$, індексом передніх рогів (r=-0,169, $\mathrm{p}=0,000)$, БФІ $(\mathrm{r}=0,167$, $\mathrm{p}=0,005)$. А також зв'язок із відсотком $\mathrm{AnV}^{+}$та шириною третього шлуночка $(\mathrm{r}=0,224, \mathrm{p}=0,000)$, $\mathrm{AnV}^{+}$і шириною субарахноїдального простору на рівні Сільвієвої щілини $(\mathrm{r}=0,175, \mathrm{p}=0,003)$.

До групи 3 морфометричними ознаками ПЦА увійшли пацієнти 3 проявами зовнішньої $(n=55)$, внутрішньої $(n=29)$ та змішаної $(n=58)$ церебральної атрофії. Результати дослідження в даних групах вмісту лейкоцитів, збагачених АФК ${ }^{+}$, а також клітин у стадії некрозу та апоптозу представлені в таблиці 1.

Достовірної різниці між значеннями АФК $\%$ та $\mathrm{AnV}^{+}, \%$ у групах встановлено не було. Лише показник $\mathrm{PI}^{+}, \%$ у групі з морфометричними ознаками змішаної ПЦА були достовірно вищими за відповідне значення в групі з зовнішньою ПЦА.

У пацієнтів із зовнішнім варіантом ПЦА кореляційна залежність між концентрацією $\mathrm{AnV}^{+}, \%$ та індексом тіл бокових шлуночків ( $\mathrm{r}=-0,410, \mathrm{p}=$ $0,002)$, БКІ (r=-0,314, $\mathrm{p}=0,021)$. У групі з морфометричними ознаками внутрішньої ПЦА зв'язок між $\mathrm{AФК}^{+}, \%$ та шириною бокових шлуночків $(\mathrm{r}=0,439$, $\mathrm{p}=0,017$ - правого та $\mathrm{r}=0,556, \mathrm{p}=0,002$ - лівого), $\mathrm{AnV}^{+}, \%$ та середнім значенням ширини субарахноїального простору $(\mathrm{r}=0,419, \mathrm{p}=0,023)$.

У пацієнтів із змішаною ПЦА встановлено такі кореляційні зв'язки: АФК ${ }^{+}$ширина субарахноїдальних просторів на рівні лобових часток $(\mathrm{r}=0,560, \mathrm{p}=0,000)$, АФК ${ }^{+}$індекс переднього рога $(\mathrm{r}=-0,749, \mathrm{p}=0,000)$, АФК ${ }^{+}$індекс тіл бокових шлуночків (r=0,667, $\mathrm{p}=0,000), \mathrm{A \Phi K}^{+} / \mathrm{\Psi X} \quad(\mathrm{r}=$ $0,438, \mathrm{p}=0,001), \mathrm{AФК} /$ БКI $(\mathrm{r}=0,673, \mathrm{p}=0,000)$, a також, $\mathrm{PI}^{+} /$індекс тіл бокових шлуночків (r=$0,260, \mathrm{p}=0,048)$.

Отже, отримані результати дозволяють констатувати наявність залежності між морфометричними маркерами ПЦА та показниками, які характеризують стан процесів апоптозу та оксидантного стресу в периферичній крові. Зважаючи на дані літератури [9], про можливу роль ЧМТ у розвитку нейродегенеративної патології, і хвороби Альцгеймера зокрема, а також той факт, що однією 3 диференційних візуалізаційних ознак нейродегенерації $\epsilon$ кортикоатрофічний процес, взаємозв'язок між підвищеним рівнем лейкоцитів периферичної крові у фазі апоптозу та морфометричними індексами потребують подальшого дослідження (табл. 2).

Не встановлено достовірної відмінності між показниками оксидантного стресу та $\mathrm{PI}^{+}$у пацієн-

Таблиця 1

Вміст АФК ${ }^{+}, \mathrm{PI}^{+}, \mathrm{AnV}^{+}$у пацієнтів із морфометричними ознаками післятравматичної церебральної атрофії, \%

\begin{tabular}{|c|c|c|c|c|}
\hline \multirow{3}{*}{ Показник } & \multicolumn{3}{|c|}{ Вид ПЦА } & \multirow{3}{*}{$\begin{array}{c}\text { Примітка: p- } \\
\text { достовірність різни- } \\
\text { ці між групами }\end{array}$} \\
\hline & $\begin{array}{c}\text { зовнішня, } \\
\mathrm{n}=55\end{array}$ & внутрішня, n=29 & $\begin{array}{c}\text { змішана, } \\
\mathrm{n}=58\end{array}$ & \\
\hline & 1 & 2 & 3 & \\
\hline $\mathrm{A} \Phi \mathrm{K}^{+}, \%$ & $40,70 \pm 1,61$ & $40,16 \pm 2,95$ & $41,91 \pm 1,75$ & $\begin{array}{l}1-2=0,34 \\
1-3=0,50 \\
2-3=0,84\end{array}$ \\
\hline $\mathrm{PI}^{+}, \%$ & $1,62 \pm 0,12$ & $1,84 \pm 0,22$ & $2,02 \pm 0,17$ & $\begin{array}{l}1-2=0,26 \\
1-3=0,05 \\
2-3=0,48\end{array}$ \\
\hline $\mathrm{AnV}^{+}, \%$ & $29,36 \pm 1,12$ & $28,35 \pm 1,56$ & $31,22 \pm 1,26$ & $\begin{array}{l}1-2=0,64 \\
1-3=0,46 \\
2-3=0,11\end{array}$ \\
\hline
\end{tabular}


Таблиця 2

Вміст АФК ${ }^{+} \mathrm{PI}^{+}, \mathrm{AnV}^{+}$у пацієнтів із морфометричними ознаками післятравматичної церебральної атрофії залежно від тяжкості черепно-мозкової травми, \%

\begin{tabular}{|c|c|c|c|c|}
\hline \multirow{3}{*}{ Показник } & \multicolumn{3}{|c|}{ Вид ЧМТ } & \multirow{3}{*}{$\begin{array}{c}\text { Примітка } \\
\text { P }\end{array}$} \\
\hline & $\begin{array}{c}\text { ЛЧМТ, } \\
\mathrm{n}=55\end{array}$ & $\begin{array}{c}\text { СТЧМТ, } \\
\text { n=29 }\end{array}$ & $\begin{array}{c}\text { TЧMT, } \\
\mathrm{n}=58\end{array}$ & \\
\hline & 1 & 2 & 3 & \\
\hline $\mathrm{A} \Phi \mathrm{K}^{+}, \%$ & $39,31 \pm 1,84$ & $40,23 \pm 2,30$ & $42,40 \pm 1,75$ & $\begin{array}{l}1-2=0,53 \\
1-3=0,41 \\
2-3=0,21\end{array}$ \\
\hline $\mathrm{PI}^{+}, \%$ & $1,57 \pm 0,13$ & $1,87 \pm 0,23$ & $1,99 \pm 0,15$ & $\begin{aligned} 1-2 & =0,34 \\
1-3 & =0,06 \\
2-3 & =0,98\end{aligned}$ \\
\hline $\mathrm{AnV}^{+}, \%$ & $32,78 \pm 1,40$ & $29,66 \pm 1,42$ & $28,23 \pm 1,09$ & $\begin{array}{l}1-2=0,58 \\
1-3=0,00 \\
2-3=0,41\end{array}$ \\
\hline
\end{tabular}

тів із морфометричними ознаками ПЦА, що перенесли ЧМТ різного ступеня тяжкості. Лише рівень клітин у стадії раннього апоптозу був достовірно вищим у пацієнтів із наслідками ЛЧМТ. Співвідношення $\mathrm{PI}^{+} / \mathrm{AnV}^{+}$становило 1:20,5 (ЛЧМТ), 1:15,8 (СТЧМТ), - 1:14,3 (ТЧМТ), що підтверджує активацію процесів апоптозу у групі осіб із наслідками ЛЧМТ.

У пацієнті з наслідками ЛЧМТ встановлено помірний кореляційний зв'язок між вмістом $\mathrm{AnV}^{+}$ та шириною третього шлуночка $\mathrm{r}=0,312, \mathrm{p}=0,002$, легкий - між $\mathrm{AnV}^{+}$та шириною субарахноїдального простору на рівні Сільвієвої щілини $\mathrm{r}=0,244$, $\mathrm{p}=0,018$, індексом Шлатенбрандта-Нюрнберга $\mathrm{r}=-$ $0,237, \mathrm{p}=0,021$. За умови СТЧМТ в анамнезі, зв'язок $\mathrm{AnV}^{+}$/ширина третього шлуночка $\mathrm{r}=0,467$, $\mathrm{p}=0,000, \mathrm{AnV}^{+} /$індекс Шлатендрандта-Нюрнберга $\mathrm{r}=0,462, \mathrm{p}=0,000$. Негативний вплив АФК+ позначився на: БФІ $\mathrm{r}=0,286, \mathrm{p}=0,015$, ЧХ $\mathrm{r}=0,275$, p=0,019, CE r=0,303, p=0,010 у групі з наслідками СТЧМТ та на ширині субарахноїдального простору на рівні Сільвісвої щілини $\mathrm{r}=0,280, \mathrm{p}=0,003$ та потиличної частки $\mathrm{r}=0,337, \mathrm{p}=0,00$ у хворих 3 наслідками ТЧМТ.

Пацієнтів 3 ознаками ПЦА розподілили за катамнезом травми на чотири групи:

- I, до 1 року $(\mathrm{n}=36)-\left(\mathrm{A} Ф \mathrm{~K}^{+}-(42,87 \pm 2,94)\right.$

$\left.\%, \mathrm{PI}^{+}-(1,78 \pm 0,14) \%, \mathrm{AnV}^{+}-(31,63 \pm 1,35) \%\right)$;

- II, $1-5$ років $(\mathrm{n}=37)-\left(\mathrm{AФК}{ }^{+}-(37,57 \pm 1,69)\right.$ $\left.\%, \mathrm{PI}^{+}-(2,12 \pm 0,26) \%, \mathrm{AnV}^{+}-(27,86 \pm 1,40) \%\right)$;

- III, 6-10 років $(\mathrm{n}=29)$ - $\left(\mathrm{AФK}^{+}-\right.$ $(40,90 \pm 2,44) \%, \mathrm{PI}^{+}-(1,67 \pm 0,18) \%, \mathrm{AnV}^{+}-$ $(28,38 \pm 1,82) \%)$;

- IV, більше 10 років $(\mathrm{n}=40)-\left(\mathrm{A \Phi K}^{+}-\right.$ $(43,29 \pm 1,94) \%, \mathrm{PI}^{+}-(1,73 \pm 0,16) \%, \mathrm{AnV}^{+}-$ $(31,16 \pm 1,40) \%)$.

Аналізуючи наведені дані, встановили схожість у динаміці показників $\mathrm{AФK}^{+}$та $\mathrm{AnV}^{+}$- максимальні значення в період до одного року з подальшим зниженням у групі 3 катамнезом 1-5 років та поступовим наростанням у наступних. Зафіксований факт достовірного зростання рівня оксидантного стресу у IV групі (порівняно з II) та достовірного $(\mathrm{p}=0,05)$ зменшення відсотка клітин у стадії апоптозу в II групі (порівняно зі значеннями I групи).

У пацієнтів із катамнезом травми до одного року встановлено кореляційний зв'язок $\mathrm{AФК}^{+} /$ ширина бокового шлуночка $\mathrm{r}=+0,39, \mathrm{p}=0,022$, АФК ${ }^{+}$/ширина великої цистерни $\mathrm{r}=+0,37, \mathrm{p}=0,029$, $\mathrm{AnV}^{+}$/ширина третього шлуночка $\mathrm{r}=+0,42$, $\mathrm{p}=0,011, \mathrm{AnV}^{+}$-ширина субарахноїдального просTopy $\mathrm{r}=+0,38, \mathrm{p}=0,028, \mathrm{AnV}^{+} / \mathrm{A} / \mathrm{E} \mathrm{r}=-0,45, \mathrm{p}=0,008$, $\mathrm{AnV}^{+} /$ширина великої цистерни $\mathrm{r}=+0,41, \mathrm{p}=0,017$.

У пацієнтів із катамнезом травми у 1-5 років діагностовано кореляційну залежність між шириною субарахноїдального простору на рівні полюса лобових часток та АФК+ $(\mathrm{r}=+0,35, \mathrm{p}=0,36)$ i $\mathrm{AnV}^{+}(\mathrm{r}=0,36, \mathrm{p}=0,028)$.

Зафіксовано вплив оксидантного стресу на: значення індексу передніх рогів $(\mathrm{r}=-0,42$, $\mathrm{p}=0,026)$, БКІ $(\mathrm{r}=-0,39, \mathrm{p}=0,040)$ при катамнезі травми у 6-10 років. У цій групі кореляційний зв'язок між відсотком клітин у стадії некрозу та шириною субарахноїдального простору на рівні полюса лобових часток $\mathrm{r}=-0,39, \mathrm{p}=0,041$. У пацієнтів із ЧМТ більше 10 років тому - $\mathrm{A \Phi K^{+ }} /$ ширина субарахноїдального простору на рівні лобових часток $\mathrm{r}=-0,31, \mathrm{p}=0,50$.

\section{Висновки}

1. За наявності ознак післятравматичної церебральної атрофії у пацієнтів із наслідками черепно-мозкової травми, діагностували достовірно вищі значення показників раннього апоптозу, активацію оксидантного стресу та тенденцію до зростання показників пізнього апоптозу.

2. Встановлено залежність між окремими морфометричними маркерами післятравматичної церебральної атрофії та показниками, які характеризують стан процесів апоптозу та оксидантного стресу в периферичній крові.

3. Серед пацієнтів із морфометричними ознаками післятравматичної церебральної атрофiï, достовірно вищий рівень $\mathrm{AnV}^{+}$був у групі 3 наслідками легкої черепно-мозкової травми.

4. Зафіксовані особливості динаміки показників $\mathrm{AФK}^{+}$та $\mathrm{AnV}^{+}$- максимальні значення в період до одного року з подальшим зниженням у 
групі з катамнезом 1-5 років та поступовим наростанням у наступних.

Перспективи подальших досліджень дослідження клініко-морфологічних співвідношень у пацієнтів із наслідками ЧТМ.

\section{Література}

1. Карасева Т.А. Посттравматическая церебральная атрофия (вопросы военно-медицинской экспертизы) / Т.А Карасева // Известия высших учебных заведений. Поволжский регион. Медицинские науки. - 2012. № 2 (22). - С. 109-116.

2. Компьютерно-томографические особенности черепномозговой травмы различного характера / М.В. Сагель, Р.К. Корженевич, И.И. Шоломов [и др.] // Саратов. науч.-мед. ж. - 2007. - № 3 (17). - С. 73-75.

3. Салій 3.В. Клініко-лабораторні співвідношення при черепно-мозковій травмі / 3.B. Салій // Science Rise. 2015. - № 8/3 (13). - C. 58-64.

4. Greve M.W. Pathophysiology of traumatic brain injury / M.W. Greve, B.J. Zink // Mt Sinai J. Med. - 2009. - № 76 (2). - P. 97-104.
5. Voluntary exercise or amphetamine treatment, but not the combination, increases hippocampal brain-derived neurotrophic factor and synapsin I following cortical contusion injury in rats / G.S. Griesbach, D.A. Hovda, F. GomezPinilla [et al.] // Neuroscience. - 2008. - № 154 (2). P. $530-540$.

6. Serial Serum Leukocyte Apoptosis Levels as Predictors of Outcome in Acute Traumatic Brain Injury / Hung-Chen Wang, Tzu-Ming Yang, Yu-Jun Lin // Bio Med Research International. - 2014. - № 72. - P. 11.

7. Jain K.K. Neuroprotection in traumatic brain injury / K.K Jain // Drug Discov. Today. - 2008. - № 13 (23-24). - P. 1082-1089.

8. Li W. Caveolin-1 Inhibits Expression of Antioxidant Enzymes through Direct Interaction with Nuclear Erythroid 2 p45-related Factor-2 (Nrf2) / W. Li, H. Liu, J-S. Zhou // The J. of Biological Chemistry. - 2012. № 287 (25). - P. 20922-20930.

9. Distinct MRI Atrophy Patterns in Autopsy-Proven Alzheimer's Disease and Frontotemporal Lobar Degeneration / G.D. Rabinovici, W.W.Seeley, E.J. Kim [et al.] // Am. J. of Alzheimer's Disease and Other Dementias. 2007. - № 22 (6). - P. 474-488.

\section{СОДЕРЖАНИЕ АФК ${ }^{+}$PI $^{+}, \mathrm{ANV}^{+}$У БОЛЬНЫХ С ПОСЛЕДСТВИЯМИ ЧЕРЕПНО-МОЗГОВОЙ ТРАВМЫ В ЗАВИСИМОСТИ ОТ МОРФОМЕТРИЧЕСКИХ ХАРАКТЕРИСТИК ГОЛОВНОГО МОЗГА}

\section{3.В. Салий}

Резюме. В статье приведены результаты исследования содержания $\mathrm{AФK}^{+}, \mathrm{AnV}^{+}$и $\mathrm{PИ}^{+}$у пациентов с последствиями ЧМТ в зависимости от морфометрических характеристик головного мозга. Установлено достоверно более высокие значения показателей раннего апоптоза, активацию оксидантного стресса и тенденцию к росту показателей позднего апоптоза при наличии признаков посттравматической церебральной атрофии. Зафиксированы особенности динамики показателей $\mathrm{AФK}^{+}$и $\mathrm{AnV}^{+}$в группах с различным катамнезом травмы, а также зависимость между отдельными морфометрическими маркерами церебральной атрофии и показателями, которые изучались.

Ключевые слова: активные формы кислорода, апоптоз лейкоцитов, последствия черепно-мозговой травмы.

\section{CONTENT OF AFO ${ }^{+}, \mathrm{ANV}^{+}$AND PI $^{+}$IN PATIENTS WITH CONSEQUENCES OF TBI ACCORDING TO MORPHOMETRIC CHARACTERISTICS OF THE BRAIN}

\section{Z.V.Salii}

Abstract. The article contains information about the results of the investigation of content of $\mathrm{AFO}^{+}, \mathrm{AnV}^{+}$and $\mathrm{PI}^{+}$in patients with consequences of TBI according to morphometric characteristics of the brain. Significantly higher content of early apoptosis indexes, activation of oxidative stress and tendency to increasing of late apoptosis indexes on the background of posttraumatic cerebral atrophy signs were established. The peculiarities of dynamics of $\mathrm{AFO}^{+}$and $\mathrm{AnV}^{+}$in groups with different TBI case history were investigated. The relationship between the individual morphometric markers of cerebral atrophy and above mentioned indexes was established.

Key words: active forms of oxygen, apoptosis of leukocytes, consequences of traumatic brain injury.

HSEI «I.Y. Horbachevskyi State Medical University» (Ternopil)

Рецензент - доц. В.Я. Шутка

Buk. Med. Herald. - 2016. - Vol. 20, № 2 (78). - P. 144-147

Надійшла до редакції 28.03.2016 року

(c) 3.В. Салій, 2016 